\title{
Ancaman Berita Bohong di Tengah Pandemi Covid-19
}

\author{
Hanik Chumairoh \\ Program Studi Pemikiran Politik Islam IAIN Kudus \\ e-mail: hanikchumairoh3009@gmail.com
}

\begin{abstract}
Abstrak
Di era digital seperti ini, masyarakat bebas memiliki akun pribadi yang menjadi wadah untuk mennyalurkan aspirasi mereka baik melalui lisan, media cetak, maupun media elektronik/online. Namun jika penggunaannya tidak terkontrol akan memberi dampak negatif bagi masyarakat. Artikel ini setidaknya menyebutkan dua faktor penyebab merebaknya berita bohong atau hoax, yaitu sikap seseorang terhadap kelompok, produk dan kebijakan. Kedua terkait terbatasnya pengetahuan penyebar dan penerima.
\end{abstract}

Kata Kunci:

Hoax, Media Sosial, Covid-19

\section{PENDAHULUAN}

Tulisan ini akan mengulas tentang informasi yang menuai kontroversi di media sosial, banyaknya berita-berita yang meresahkan masyarakat beredar di dunia maya atau sering disebut berita hoax. Kebebasan yang tidak berbudaya dan beretika akan membawa konsekuensi hukum, untuk itu harus berhati-hati dalam mempergunakan media sosial. Seseorang bebas mengeluarkan pendapatnya di negeri ini untuk berekspresi dan bereksperimen di depan publik, namun urusan benar atau salah, jujur atau bohong menjadi hal yang kurang diperhatikan oleh penyebar berita, yang penting dapat dibaca dan diketahui oleh publik secara cepat dan luas. ${ }^{1}$ Hal ini mendapatkan perhatian dari pemerintah, dalam upaya menangkal berita hoax yang telah beredar luas di masyarakat.

Kebebasan berpendapat telah diatur dalam perundang-undangan, baik yang tertuang pada hukum internasional Pasal 29 Deklarasi Universal Hak-Hak Asasi Manusia maupun Pasal 28 UndangUndang Dasar 1945. Regulasi ini telah mengatur soal kebebasan bagi masyarakat untuk mengekspresikan diri dan mengeluarkan pendapatnya dan itu sudah menjadi hak yang melekat padanya sesuai undang-undang yang berlaku.

\footnotetext{
${ }^{1}$ Wahid Nashihuddin, "Pustakawan, Penangkal Informasi Hoax di Masyarakat", Artikel Tidak Dipublikasikan (2017), h. 1-10.
} 
Namun sekalipun telah diatur dalam regulasi, akan tetapi jika menilik kembali media sosial justru media sosial mendorong adanya perubahan dalam pola identitas masyarakat cyber dan pola pendistribusian informasi yang selama ini telah terkotak-kotakkan. ${ }^{2}$ Dalam media sosial kita seringkali menjumpai pola kejahatan baru yang dapat mempengaruhi publik dan disarkan pada informasi palsu atau hoax. Kejahatan hoax dapat di kategori sebagai cyber crime. Cyber crime merupakan tindak kejahatan yang dilakukan oleh oknum tertentu dengan menggunakan teknologi komputer khususnya melalui internet atau media elektronik.

Begitupun isu Covid-19, telah banyak beredar informasi palsu yang meresahkan masyarakat. Sebagaimana kita ketahui bahwa Covid-19 atau Virus Corona adalah virus yang menyerang sistem pernapasan manusia, ada gejala yang akan ditimbulkan ketika seseorang terkena virus tersebut seperti batuk, pilek, demam, sakit tenggorokan, sulit bernafas, dan merasa mudah lelah. Penyebaran virus ini juga menjadikan psikis, mental, hingga kekhawatiran yang berlebihan akan bahanya. Virus ini bisa menyerang siapa saja, baik bayi, remaja hingga orang dewasa. Virus ini ditemukan di Wuhan, China, pada akhir Desember 2019 lalu dan telah menyebar di negara China bahkan

\footnotetext{
${ }^{2}$ Dewi Maria Herawati, "Penyebaran Hoax dan Hate Speech sebagai Representasi Kebebasan Berpendapat", PROMEDIA, Vol. II, No. 2 (2016), h. 138-155.
}

sampai negara lain, salah satunya Indonesia.

Menyebarnya berita virus tersebut awalnya di sepelekan pemerintah, bahwa Indonesia bebas dari Covid-19. Media sosial di tanah air sempat ramai menuding bahwa pemerintah berupaya menutupi fakta terkait dengan penyebaran virus Covid-19. Pemerintah pun mengklarifikasi bahwa Indonesia masih nihil alias bebas virus Covid-19.

\section{KAJIAN PUSTAKA}

Kajian tentang berita bohong atau berita palsu atau hoax telah banyak dipublikasikan oleh penulis lain, misalnya tulisan Dewi Maria Herawati dengan judul Penyebaran Hoax dan Hate Speech sebagai Representasi Kebebasan Berpendapat. Herawati dalam tulisannya mengemukakan bahwa kebebasan dalam dunia maya dapat menimbulkan permasalahan baru bagi masyarakat dikarenakan sangat mudah menyebarkan informasi yang belum jelas kebenarannya, apalagi menyangkut ujaran-ujaran kebencian. Semuanya itu didasari dengan alasan yang sama, yaitu hak untuk bebas berpendapat. $^{3}$

Begitupun tulisan Abd. Majid tentang Fenomena Penyebaran Hoax dan Literasi Bermedia Sosial Lembaga Mahasiswa Universitas Muslim Indonesia. Majid mengatakan bahwa mahasiswa menyebarkan informasi ke group lembaga atau publik terkadang tanpa didahului dengan

${ }^{3}$ Dewi, 2016, h. 138-155. 
membaca secara teliti, memahami, mengecek kebenaran berita tersebut, sehingga kemudian berita menjadi viral karena dibagikan secara terus menerus kepada orang lain. ${ }^{4}$ Sementara itu Nur Aisyah Siddiq menulis tentang penegakan hukum untuk menanggulangi pemberitaan palsu. ${ }^{5}$

Dari tiga literatur di atas dapat disimpulkan bahwa media sosial merupakan salah satu pusat informasi yang menghubungkan antara seseorang dengan orang lain yang sering kali membawa dampak negatif jika informasi yang disampaikan berisi konten berita bohong atau hoax. Dalam Kamus Besar Bahasa Indonesia (KBBI) kata hoax mengandung arti tidak benar bohong atau dapat diartikan bahwa hoax adalah sebuah pemberitaan palsu yang tidak dapat dipertanggungjawabkan kebenarannya.

Di tengah masa pandemi Covid-19 seperti saat ini, seringkali kita menemukan informasi palsu di media sosial, bahkan dikaitkan dengan isu politik yang cukup hangat di tengah masyarakat.

Di era digital seperti ini, masyarakat bebas memiliki akun pribadi yang menjadi wadah untuk mennyalurkan aspirasi mereka baik melalui lisan, media cetak,

\footnotetext{
${ }^{4}$ Abd. Majid, "Fenomena Penyebaran Hoax dan Literasi Bermedia Sosial Lembaga Mahasiswa Universitas Muslim Indonesia”, Jurnal Komodifikasi, Vol. 8 (2019), h. 228-239.

${ }^{5}$ Nur Aisyah Siddiq, "Penegakan Hukum Pidana dalam Penanggulangan Berita Palsu (Hoax) Menurut Undang-Undang No.11 Tahun 2008 Yang Telah Dirubah Menjadi Undang-Undang No.19 Tahun 2016 Tentang Informasi dan Transaksi Elektronik", Lex Et Societatis Vol. V, No. 10 (2017), h. 26-32.
}

maupun media elektronik/online. Akan tetapi media sosial juga bisa menjadi batu loncatan bagi sebagian oknum-oknum tertentu yang menyalahgunakan media tersebut untuk menyebarkan berita bohong atau hoax. Maka dari itu, sebagai penerima informasi masyarakat harus berhati-hati dan lebih teliti terhadap informasi publik.

\section{METODE PENELITIAN}

Metode yang digunakan oleh peneliti adalah metode kualitatif untuk mencari informasi dan perkembangan pada era media baru. Sumber data penelitian diambil dari sumber sekunder di mana data diperoleh dari berbagai tulisan, dokumen dan media sosial terkait dengan isu-isu hoax di tengah merebaknya Covid19. Adanya penerapan social distansing membuat peneliti harus memanfaatkan sebaik mungkin studi teks, dokumen berita, serta artikel yang memuat berita hoax.

\section{PEMBAHASAN}

\section{Media Baru, Hoax dan Regulasi}

Proses komunikasi yang sekarang ini telah tergeser dari media konvensional sekarang dengan perkembangan zaman digantikan oleh media cetak dan elektronik. Dalam menghadapi era globalisasi pergaulan hidup antara manusia dengan lingkungan merupakan faktor utama dalam membentuk kepribadian dan perkembangan jiwa manusia. Sebab manusia tidak akan mengalami perkembangan fisik dan psikis yang baik juga. Peran komunikasi dalam politik sangat penting karena tanpa 
komponen komunikasi, infrastruktur dan suprastruktur akan mengalami putus hubungan sehingga mekanisme yang harusnya dijalankan tidak berkembang secara dinamis. Dengan memanfaatkan komunikasi sebagai proses politik, berbagai tatanan politik yang tidak sesuai dengan tuntutan masyarakat akan berubah. $^{6}$

Krisis ruang publik dan komunikasi politik yang ditampilkan media konvensional, membuat teknologi media baru makin menampakkan karakter transformatifnya. Artinya media baru menjadi jawaban tepat untuk merevitalisasi kembali ruang publik dan komunikasi politik yang sudah terkolonialisasi oleh kepentingan modal. ${ }^{7}$ Karena berbasis internet, media baru ini kemudian bersifat fleksibel dapat diakses di manapun sepanjang terkoneksi jaringan internet. Berbeda dengan media massa konvensional yang bersifat satu arah, media baru bersifat interaktif. Ia dapat digunakan secara privat untuk kalangan terbatas, maupun digunakan terbuka untuk publik yang luas. $^{8}$

Dalam perkembangannya ini juga memiliki dampak positif dan negatif. Salah satu dampak positif adalah menjadikan masyarakat lebih kekinian dalam mendidik dan menanamkan nilai moral kepada generasi milenial, sedangkan

\footnotetext{
${ }^{6}$ Zaenal Mukarom, Komunikasi Politik (Bandung: Pustaka Setia, 2016), h. 24.

${ }^{7}$ Zaenal, 2016.

${ }^{8}$ Salvatore Simarmata, "Media Baru, Ruang Publik Baru, dan Transformasi Komunikasi Politik di Indonesia", Interact, Vol. 3, No. 2 (2014), h. 18-36.
}

dampak negatif salah satunya menyebarkan berita hoax dan isu SARA dalam moral masyarakat.

Hoax adalah suatu informasi yang ditambah-tambahi atau dikurang-kurangi isi dari berita yang sebenarnya terjadi. Adanya unsur manipulasi atau modifikasi guna mendapat respon yang cukup banyak dan menjadi viral. Seperti halnya berita penyebaran Covid-19 di daerah yang belum dipastikan kebenaranya, menimbulkan kekhawatiran bagi masyarakat sekitar. Pemicu informasi hoax memiliki dua motif yaitu ekonomi dan politik. Ada situs-situs yang memang sengaja dibuat dengan tujuan mendapatkan kunjungan sebanyak mungkin, dengan membuat berita penuh sensasi. Selain itu ada juga yang motifnya untuk menyalurkan aspirasi politik melalui media sosial dengan membuat kabar palsu. ${ }^{9}$ Sehingga muncul degradasi moral yakni, suatu kemerosotan dan lunturnya sikap, budi pekerti, perilaku seseorang atau kelompok.

Hoax memberikan pengaruh kepada setiap orang yang membaca berita hoax agar orang tersebut percaya dengan berita tersebut seolah benar adanya. ${ }^{10}$ Seseorang yang menuliskan, menyampaikan, bahkan sampai menggunakan suatu informasi untuk membuat masyarakat yakin terhadap informasi itu, padahal informasi itu

\footnotetext{
${ }^{9}$ Ika Pomounda,'Perlindungan Hukum Bagi Korban Penipuan Melalui Media Elektronik (Suatu Pendekatan Viktimologi)", Jurnal Ilmu Hukum Legal Opinion, Vol. 3, No. 4 (2015).

${ }^{10}$ Christiany Juditha, "Interaksi Komunikasi Hoax di Media Sosial serta Antisipasinya", Jurnal Pekommas, Vol. 3, No. 1 (2018), h. 31-44.
} 
tidaklah benar maka disebut sebagai penyebar berita palsu.

Pemerintah telah menetapkan hukum positif yamg mengatur mengenai tindak pidana penyebaran informasi hoax di Indonesia diantaranya terdapat dalam pasal 14 dan 15 Undang-Undang Nomor 1 tahun 1946 tentang Peraturan Hukum Pidana serta Undang-Undang No 19 Tahun 2016 tentang Perubahan UndangUndang No. 11 Tahun 2008 tentang Informasi dan Transaksi Elektronik diatur di dalam Pasal 28 ayat (1) jo Pasal 45 (A).

Pemberitaan bohong (hoax) diolah sedemikian rupa agar menarik minat pembaca, para warganet turut serta dalam kolom komentar untuk membahas suatu berita dengan anggapan mereka dapat meluruskan berita tersebut melalui opininya. Padahal belum tentu apa yang mereka sampaikan dapat dimengerti orang lain, sehingga semakin banyak yang ikut serta baik mengomentari berita itu sendiri maupun argumen orang lain. Berita bohong banyak yang lebih populer sehingga menutupi keberadaan berita aslinya. Wabah hoax telah menjadi masalah nasional antara lain perpecahan, instabilitas politik dan gangguan keamanan yang berpotensi menghambat pembangunan nasional. ${ }^{11}$

Salah satu contoh berita-berita yang dianggap mempengaruhi publik adalah berita tentang bantuan sosial (bansos) di tengah pandemi Covid-19. Pemberitaan

\footnotetext{
${ }^{11}$ Nur Aisyah Siddiq, 2017, h. 26-32.
}

terkait ini, terutama di daerah mewarnai media sosial kita, baik beritanya benar maupun palsu ikut membanjiri media sosial. Olehnya itu, masyarakat dihimbau untuk lebih berhati-hati dalam menerima informasi di tengah ekonomi masyarakat yang terbengkalai di masa pandemi Covid19. Banyak sekali isu bantun sosial yang tidak tepat sasaran membuat persepsi publik terkait kebijakan bantuan sosial (bansos) berubah dari positif menjadi negatif.

Pemantauan Wakil Direktur Institue for Development of Economics and Finance (Indef), Eko Listiyanto di media sosial khususnya twitter awalnya terlihat publik menyambut baik kebijakan pemerintah menetapkan sejumlah bansos, mulai dari bansos sembako sampai bansos tunai mendapat respon cukup positif, tapi kemudian keluhan di tingkat daerah cukup banyak terkait pelaksanaan penyaluran bansos yang tidak terarah dan tumpang tindih sehingga dianggap menjadi penyebab masyarakat tidak lagi meman-dang program bansos secara positif. Jika tidak ada perbaikan maka akan berujung pada konflik sosial di lingkup masya-rakat. ${ }^{12}$

\section{Faktor Munculnya Hoax}

Berita haox saat ini menjadi ancaman informasi karena efeknya yang berbahaya dan berhubungan dengan hukum. Hebohnya dunia maya yang diwarnai dengan

\footnotetext{
${ }^{12}$ Verda Nano Setiawan, "Bansos Dampak Corona Tak Tepat Sasaran, Citra Pemerintah Dinilai Turun" dalam https://katadata.co.id/berita/ 2020/04/26/bansos-dampak-corona-tak-tepat-sas aran-citra-pemerintah-dinilai-turun diakses 1 Mei 2020.
} 
kebohongan membuat negara mengambil tindakan tegas terhadap hal tersebut. Masyarakat yang memiliki hak dalam menyampaikan opini, kreatifitas, dan lain sebagainya menjadi ruang publik yang cukup strategis untuk mendapatkan dan menyalurkan informasi, tetap bertanggungjawab atas apa yang disebaran.

Pemerintah telah memberikan sanksi untuk pelaku yang menuliskan dalam media sosialnya berisi ujaran kebencian terhadap suatu kaum/agama dan bertujuan menghasut masyarakat atau ikut menyudutkan suatu kaum akan dikenakan Pasal 45A Ayat 2 Undang-Undang ITE. Pertanggungjawaban sebagai pelaku penistaan SARA di jejaring sosial dapat dikatakan sebagai Penjahat. ${ }^{13}$

Secara psikologis, menurut Laras Sekarasih sebagai dosen Psikologi Media dari Universitas Indonesia, tedapat dua faktor yang dapat menyebabkan seseorang sangat mudah mempercayai berita hoax. Faktor pertama ialah jika informasi yang diterima dapat menyalurkan opini setiap individu. Seperti seseorang yang memang sudah tidak setuju terhadap kelompok tertentu, produk, atau kebijakan tertentu. Ketika ada informasi yang dapat mengafirmasi opini dan sikapnya tersebut, maka ia mudah percaya. Hal tersebut juga berlaku pada kondisi sebaliknya. Seseorang yang terlalu suka terhadap

\footnotetext{
${ }^{13}$ Tessalonicha Leuwo, "Penerapan Sanksi Pidana Terhadap Pelaku Cyber Crime Yang Menyebarkan Isu Suku, Ras, Agama Dan Antar Golongan (SARA) Melalui Media Sosial Ditinjau Dari Undang-Undang ITE Nomor19 Tahun 2016", Lex Crime,.Vol. VII, No. 2 (2018), h. 27-34.
}

kelompok, produk, dan kebijakan tertentu, jika menerima informasi yang sesuai dengan apa yang ia percayai, maka keinginan untuk melakukan pengecekan kebenaran terlebih dahulu menjadi berkurang. Secara natural, perasaan positif akan timbul di dalam diri seseorang ketika ada yang mengafirmasi apa yang dipercayai. Perasaan terafirmasi tersebut juga menjadi pemicu seseorang dengan mudahnya meneruskan informasi hoax ke pihak lain. $^{14}$

Faktor kedua yang menyebabkan seseorang mudah percaya pada hoax ialah disebabkan terbatasnya pengetahuan. Paparan tentang rendahnya daya literasi masyarakat Indonesia di atas menjadi jawaban terbaik atas pertanyaan mengapa hoax amat mudah tersebar dan menjadi persoalan nasional serius dewasa ini. Pengetahuan yang rendah menyebabkan filter untuk menyaring informasi yang datang dari media-khususnya media baru-, media sosial melalui jaringan internet tidak cukup kuat untuk menyaring dan mengonfirmasi berita. ${ }^{15}$

Faktor kedua ini sering kita jumpai, khususnya masyarakat desa yang kurang mengerti dunia media sosial secara spesifik. Desa selama ini dipersepsi sebagai sebuah wilayah dengan karakteristik atau ciri-ciri berupa kesederhanaan, keluguan, dan kepolosan. Selain itu, desa juga dianggap memiliki nilai luhur atau

\footnotetext{
${ }^{14}$ Masrudi, "Hoax, Media Baru Dan Daya Literasi Kita", Orasi: Jurnal Dakwah dan Komunikasi, Vol. 10 No. 2 (2019), h. 152-161.

${ }^{15}$ Masrudi, 2019, h. 152-161.
} 
bobot tersendiri karena mempunyai beragam kearifan lokal. ${ }^{16}$ Masyarakat desa kerap kali mengalami kesulitan memilah informasi yang beredar di media sosial, apakah berita hoax atau fakta.

Seperti halnya isu Covid-19 yang merupakan berita hangat di dunia, virus yang mudah sekali menyebar melalui kontak antar orang satu dengan orang yang lain, membahayakan dan mematikan. Berita tersebut memang ada benarnya akan tetapi bila didengar oleh orang-orang yang hanya menitik beratkan berita pada hal yang ektrim saja bisa membuat psikis seseorang terganggu dan menimbulkan rasa ketakutan yang berlebihan akan sesuatu.

Untuk itu pemerintah memberikan himbauan terhadap masyarakat agar lebih berhati-hati dalam menerima informasi. Berita hoax mulai banyak menghantuai masyarakat, Polisi pun gencarkan patroli cyber dan mendapatkan pelaku penyebar hoax soal Covid-19 di Indonesia sebanyak 41 kasus pada 23 Maret 2020. ${ }^{17}$

\section{Mencegah Meluasnya Hoax}

Seperti diketahui, sejumlah kabar bohong alias hoax beredar di tengah penyebaran Covid-19 di Indonesia, salah satunya adanya berita penutupan sejumlah gerbang

\footnotetext{
${ }^{16}$ Dadang Sugiana, Ira Mirawati \& Putri Trulline, "Peran Ulama Sebagai Opinion Leader Di Pedesaan Dalam Menghadapi Informasi Hoaks", Avant Garde, Vol. 07, No. 01 (2019), h. 1-18.

${ }^{17}$ Ahmad Bil Wahid, "Gencarkan Patroli Siber, Polri Tangani 41 Hoax soal Corona" dalam https://news.detik.com/berita/d-4949856/gencarkan -patroli-siber-polri-tangani-41-hoax-soal-corona diakses 1 Mei 2020.
}

tol menuju Jakarta karena adanya lockdown, Tenaga Kerja Asing China masuk Kendari di tengah wabah Covid-19, pasar ditutup imbas Covid-19, dan lain sebagainya.

Akibat penyebaran hoax tersebut, badan keamanan negara telah menjalankan berbagai upaya untuk menanggulangi kejahatan di bidang teknologi informasi. Kepolisian berusaha melaksanakan penyelidikan terhadap kegiatan yang berhubungan dengan tenologi komputer, teknologi informasi, teknologi elektronika, teknologi komunikasi dan teknologi penyiaran serta mempergunakan laboratorium komputer forensik dalam mendukung proses penyidikan kejahatan di dunia maya.

Dalam upaya penanggulangan tindak pidana teknologi informasi, Kepolisian telah bekerjasama dengan unit khusus di Badan Reserse Kriminal (Bareskrim) Mabes Polri yaitu Direktorat II Ekonomi dan Khusus Unit VIT dan penanggulangan cyber crime dibeberapa Kepolisian Daerah (Polda). Polisi akan memberikan pelayanan yang terbaik guna mengupas tuntas permasalahan dalam bidang teknologi informasi.

Begitupun Kementrian Komunikasi dan Informatika (Kemenkominfo) yang memiliki kekuasaan untuk mengatur dan mengolah informasi, telah menemukan 54 informasi hoax terkait Covid-19 sampai 3 
Februari terakhir yang tersebar melalui media sosial dan platfrom online. ${ }^{18}$

Penyebaran berita hoax akan terkena pasal yang berlaku yaitu Pasal 28 Ayat 1 UU No. 11 Tahun 2008 mengenai Informasi dan Transaksi Elektronik, juga ada pasal terkait Pasal 45 Ayat 1 UU No. 19 Tahun 2016 tentang Perubahan Atas UndangUndang No. 11 Tahun 2008 mengenai Informasi dan Transaksi Elektronik. Pasal itu menyatakan, Setiap orang yang dengan sengaja dan tanpa hak menyebarkan berita bohong dan menyesatkan yang mengakibatkan kerugian konsumen dalam Transaksi Elektronik, dipidana penjara paling lama 6 (enam) tahun dan/atau denda paling banyak Rp 1.000.000.000,00 (satu miliar rupiah). ${ }^{19}$

Selain ancaman pidana, pemerintah juga memberikan layanan untuk masyarakat dalam mencari informasi atas kejahatan di media masa atau hoax. Kemenkoinfo telah menyediakan sarana pengaduan bagi masyarakat yang merasa dicemarkan nama baiknya melalui media masa, melalui situs https://dumas.kominfo.go.id/. Upaya yang pemerintah lakukan dalam menangkal informasi hoax yang beredar ke masyarakat, informasinya dapat diakses melalui situs online. ${ }^{20}$

\footnotetext{
${ }^{18}$ Mochamad Januar Rizki, "Langkah-langkah Mitigasi Risiko dalam Antisipasi Informasi Hoax Virus Corona" dalam https://www.hukumonline. com/berita/baca/lt5e42423f95328/langkah-langkah -mitigasi-risiko-dalam-antisipasi-informasi-hoaxvirus-corona/ diakses 1 Mei 2020.

${ }^{19}$ Mochamad, 1 Mei 2020.

${ }^{20}$ Wahid, 2017, h. 3.
}

\section{KESIMPULAN}

Kejahatan di era digital sudah sangat meresah masyarakat, seperti pembunuhan, penculikan, kriminal dan lain sebagainya. Di tengah pandemi Covid-19 banyak sekali informasi di media massa yang menjadi momok dan simpang siur akan kebenarannya. Pemberitaan yang tidak diketahui kebenarannya atau hoax menjadi salah satu kejahatan yang kian marak di dunia maya. Informasi hoax memberikan dampak negatif bagi masyarakat yang masih rendah tingkat literasinya.

$* * *$

\section{DAFTAR PUSTAKA}

Abd. Majid, "Fenomena Penyebaran Hoax dan Literasi Bermedia Sosial Lembaga Mahasiswa Universitas Muslim Indonesia”, Jurnal Komodifikasi, Vol. 8 (2019), h. 228239.

Christiany Juditha, "Interaksi Komunikasi Hoax di Media Sosial serta Antisipasinya", Jurnal Pekommas, Vol. 3, No. 1 (2018), h. 31-44.

Dadang Sugiana, Ira Mirawati \& Putri Trulline, "Peran Ulama Sebagai Opinion Leader Di Pedesaan Dalam Menghadapi Informasi Hoaks", Avant Garde, Vol. 07, No. 01 (2019), h. 118.

Dewi Maria Herawati, "Penyebaran Hoax dan Hate Speech sebagai Representasi Kebebasan Berpendapat", PROMEDIA, Vol. II, No. 2 (2016), h. 138-155. 
Ika Pomounda,'Perlindungan Hukum Bagi Korban Penipuan Melalui Media Elektronik (Suatu Pendekatan Viktimologi)", Jurnal Ilmu Hukum Legal Opinion, Vol. 3, No. 4 (2015).

Masrudi, "Hoax, Media Baru Dan Daya Literasi Kita", Orasi: Jurnal Dakwah dan Komunikasi, Vol. 10 No. 2 (2019), h. 152-161.

Nur Aisyah Siddiq, "Penegakan Hukum Pidana dalam Penanggulangan Berita Palsu (Hoax) Menurut UndangUndang No.11 Tahun 2008 Yang Telah Dirubah Menjadi UndangUndang No.19 Tahun 2016 Tentang Informasi dan Transaksi Elektronik", Lex Et Societatis Vol. V, No. 10 (2017), h. 26-32.

Salvatore Simarmata, "Media Baru, Ruang Publik Baru, dan Transformasi Komunikasi Politik di Indonesia", Interact, Vol. 3, No. 2 (2014), h. 1836.

Tessalonicha Leuwo, "Penerapan Sanksi Pidana Terhadap Pelaku Cyber Crime Yang Menyebarkan Isu Suku, Ras, Agama Dan Antar Golongan (SARA) Melalui Media Sosial Ditinjau Dari Undang-Undang ITE Nomor19 Tahun 2016", Lex Crime,.Vol. VII, No. 2 (2018), h. 27-34.

Wahid Nashihuddin, "Pustakawan, Penang-kal Informasi Hoax di Masyarakat", Artikel Tidak Dipublikasikan (2017), h. 1-10.

Zaenal Mukarom, Komunikasi Politik (Bandung: Pustaka Setia, 2016).

\section{Website}

Ahmad Bil Wahid, "Gencarkan Patroli Siber, Polri Tangani 41 Hoax soal Corona" dalam https://news.detik. com/berita/d4949856/gencarkan-patro 1-siber-polri-tangani-41-hoax-soal-co rona diakses 1 Mei 2020.

Mochamad Januar Rizki, "Langkahlangkah Mitigasi Risiko dalam Antisipasi Informasi Hoax Virus Corona" dalam https://www.hukum online.com/berita/baca/lt5e42423f953

28/langkah-langkah -mitigasi-risikodalam-antisipasi-informasi-hoaxvirus-corona/ diakses 1 Mei 2020.

Verda Nano Setiawan, "Bansos Dampak Corona Tak Tepat Sasaran, Citra Pemerintah Dinilai Turun" dalam https://katadata.co.id/berita/ 2020/04/26/bansos-dampak-coronatak-tepat-sas aran-citra-pemerintahdinilai-turun diakses 1 Mei 2020. 